\title{
The Authority of Teacher in Madrasah Based of Islamic Boarding School
}

\author{
Muhammad Ali Rohmad \\ Universitas Islam Majapahit Mojokerto \\ alirohmad86@gmail.com
}

\begin{abstract}
Teachers are obliged to possess authority to increase pedagogical interaction effectivity. However, there has been a shift in the meaning of authority so that an in-depth study is carried out on the dimensions of teacher authority, factors that influence the teacher authority, and the dynamics of teacher authority in Madrasah based of Islamic boarding school (pesantren). This research is a qualitative research by using interview, observation and documentation methods to collect the data. The data analysis includes data reduction, data display, and conclusion drawing/verification. The results show: 1) Authority is defined as strength to be admired accompanied by respect so as to bring obedience. The dimensions of teacher authority include spiritual, cognitive, affective, skills, social and physical: 2) There are at least 3 (three) factors that can increase the teacher authority, namely assertiveness, responsibility and patience; 3) The teachers authority from inside the pesantren (ndalem) is in the form of traditional authority, while teachers from outside the pesantren must strive to gain authority in the form of charismatic authority or even legal rational authority.
\end{abstract}

Keywords: Authority; teacher; Islamic boarding school. 


\begin{abstract}
Abstrak
Kewibawaan harus dimiliki oleh guru agar dapat meningkatkan efektifitas interaksi pedagogik. Namun telah terjadi pergeseran makna kewibawaan sehingga diperlukan kajian mendalam tentang dimensi wibawa guru, faktor yang mempengaruhi wibawa guru, dan dinamika wibawa guru di Madrasah berbasis pesantren. Penelitian ini merupakan penelitian kualitatif yang pengumpulan datanya menggunakan metode wawancara, observasi dan dokumentasi. Adapun analisis data meliputi data reduction, data display, dan drawing conclusion/verification. Hasilnya menunjukkan: 1) Wibawa dimaknai sebagai kekuatan untuk dikagumi yang disertai dengan rasa hormat sehingga mendatangkan kepatuhan. Dimensi wibawa guru meliputi wibawa spiritual, pengetahuan, sikap, ketrampilan, sosial, dan fisik: 2) Minimal ada 3 (tiga) faktor yang dapat meningkatkan kewibawaan guru yakni ketegasan, tanggung jawab, dan kesabaran; 3) Wibawa guru yang berasal dari dalam pesantren (ndalem) berupa traditional authority, sedangkan guru dari luar pesantren harus berusaha untuk mendapatkan kewibawaannya yang berupa charismatic authority atau bahkan legal rational authority.
\end{abstract}

Kata kunci: Wibawa; guru; pesantren

\title{
A. Introduction
}

In the world of the education, teachers are the main element in education that has not been replaced, maybe even irreplaceable. The process and results of education are greatly influenced by the presence of teachers, especially in producing quality Human Resources (Danim, 2006, p. 183). The important role of teachers in education, as well as responsibilities in the success of national education as mandated in Undang-undang RI Number 20, 2003 concerning the National Education System, among others; teachers must spearhead the achievement of idealistic educational goals. Teachers are also required to have a minimum; four competencies namely pedagogic, personality, professional, and social.

The teacher must not only master the learning material, but also must be master the spirit behind the material delivered to students (Bahrizi, 2005, p. 188). So in this case, the role and responsibility of the teacher is to form the students' behavior who have moral values, in addition to be a teacher and student supervisor.

The Prophet Muhammad could be an inspiration for teachers in pedagogical interactions, because he has the most noble personality and character, as written in the Qur'an: 


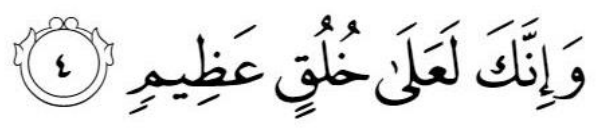

"And indeed you are of great moral character" (Q.S. al-Qalam verse 4)

Teachers should be admired, respected, followed and respected, especially by students. This is due to the weight of the roles and responsibilities assigned to the teacher. Commemoration of National Teacher's Day (HGN) every November 25 as a minimum effort in respecting teachers. However, educational thinking and learning approaches that have developed lately tend to lead to forms of education that are likely to reduce the authority of teachers.

The shift in the influence of the teacher's authority is clearly seen in Manurung's writings, which at first were so high, noble, and respected, that they have declined. In the past, the figure of a teacher was always worshiped, respected, and his attitudes and thoughts were always emulated, the teacher's authority was still thick and felt. Everything the teacher conveys is done well by the students, because it is considered a mandate that must be carried out.

To the extent that students sometimes uphold the teacher's authority over his biological parents. Students do not dare to look directly at the teacher's face, so when speaking they must bow their heads and do not dare to speak loudly. Students are also nervous and scared when talking to the teacher. That is how high the teacher's degree is (Manurung, 2008, p. 511).

The reason for the fading of the teacher's authority could also be due to Paulo Freire's thought which criticized education with the bank-style education system. This thinking is usually called the concept of pedagogy of oppressed (Freire, 2008, p. 53). In addition to this, learning approaches that are more oriented towards student competencies are increasingly in demand and are considered better (Prasetyawati, 2016, p. 130). The Child Protection Act can also be considered as one of the factors assumed to have a negative impact on teacher authority. This is also a challenge in the concept of Merdeka Belajar which was initiated by the Minister of Education and Culture at the end of 2019. As a progressive education that wants to replace authority with freedom (Tirri, 2000, p. 159). Do not let this program make students free and independent to do something negative as reported in the mass media.

The mass media reported on the actions of students who were not praiseworthy, such as the viral video of teachers who were beaten by students at SMK NU 3 Kaliwungu, Kendal, Central Java. This case made the minister of education and culture, Muhadjir Effendi on 
November 13, 2018 say that the teacher must maintain authority (Shiddiq, 2018). Also the incident that took place in Gresik in February 2019 at SMP PGRI Wringinom, where one of the students appeared to be resisting while holding his teacher's collar after being reprimanded for not smoking. A dispute also occurred at SMKN 3 Yogyakarta between students and teachers after confiscating cellphones when the test would begin (Firdaus, 2019).

There are indications that the authority of teachers is declining in Mojokerto as an intersection area between industrial areas (Surabaya and Sidoarjo), and areas of students or santri (Jombang and Kediri). One of the cases that occurred was the incident that happened to the SMKN 1 Mojoanyar Mojokerto who was reported by the police for punishing students only for enforcing discipline at school (Tempo.co, Thursday, August 25, 2016). In addition, the demonstration of hundreds of students of SMKN 1 Trowulan Mojokerto on the first day of UAS 2 December 2019, demanded that the School Principal resign due to lack of financial transparency, besides that there was a split among the head teachers and students (Radar Mojokerto Jawa Pos 3-12-2019).

Above the phenomenon shows that the authority of teachers in Mojokerto is fading. The phenomenon is actually a problem in the world of education that needs to be found a solution, because it is not just a group problem, but also involves the nation's problem (F. Syukur, 2002, p. 258). Such conditions, of course have an impact on the effectiveness of the pedagogical interaction process in educational institutions. Therefore, in-depth study and research on the authority of teachers is interesting to do, especially in Madrasah based of Islamic boarding school (pesantren).

This research is different from previous research such as Julian G. Elliott's research entitled The nature of teacher authority and teacher expertise (Elliot, 2009, p. 199). Kaarina Maatta \& Satu Uusiautti's research entitled Pedagogical authority and pedagogical love, connected or incompatible? (Maatta, 2012, p. 21). Abdillah's research entitled Relevance of Authority and Fairness with Student Learning Outcomes(Abdillah, 2012, p. 290). As well as Darul Ilmi's research entitled Authority (High Touch) as a Character Education Media (Ilmi, n.d., p. 45). All of these studies talk about how authority affects and is influenced by other factors. While this research tries to describe the form of authority in its entirety and how to achieve it in Madrasah based on Islamic boarding school with all its uniqueness.

MTs. An Nahdliyyah can be used as a representation of a Madrasah based of Islamic boarding school in Mojokerto. This institution has been operating since 2007 under the auspices of the An Nahdliyyah Islamic Boarding School which was founded in 1988. MTs An Nahdliyyah has around 250 students from various regions in East Java. This institution has a flagship program of reciting kitab kuning and memorizing Al-Qur'an. The authority of teachers 
in Madrasah based of Islamic boarding school has its own uniqueness, where the dynamics that occur include differences in student perceptions of teacher authority, or more extreme is the lack of student perceptions of the authority of teachers from inside the pesantren (ndalem) and teachers from outside the pesantren, so all teachers must be authoritative.

After the teacher gets his authority, how can this authority does not create a distance between the teacher and students. So it is necessary to reveal, among other things, dimensions of authority and the dynamics of teacher authority in Madrasah based on Islamic boarding school. The pesantren education system is considered capable of forming the mindset and behavior of students, as well as being able to provide a strong influence in forming and maintaining social, cultural, political and religious life (Dhofier, 2011, p. 13). It is hoped that the results of this study can inspire other Madrasah based of Islamic boarding school to be able to maintain and increase the authority of teachers who teach at these educational institutions.

\section{B. Discussion}

\section{The Concept of Teacher's Authority}

\section{Definition of Authority}

The "Authority" in the Big Indonesian Dictionary means circumstances or talents associated with extraordinary abilities in individual leadership to arouse the trust and admiration of others for themselves, or it can also be said that authority means the power to be admired based on the quality of personality individual (KBBI, 2002, p. 1272). In the Arabic dictionary, authority is equivalent to the term waqara which means calm, authoritative, and respectable, and close. The term haibah which means fear accompanied by respect and amazed (Munawwir, 2002, pp. 1527, 1573). The teacher's authority is explained in several books such as the book Ihya 'Ulumuddin by Al Ghazali, also in the book Ta'limul Muta'alim by Az Zarnuji who uses the term waqaar (Az-Zarnuji, tt, p. 13). Hasyim Asy'ari uses both terms in the book Adabul alim wal muta'alim (Asy'ari, 1238, p. 57).

The Authority in Javanese consists of two words, namely kawi and bhawa. Kawi can be interpreted as power, stronger power. While Bhawa can be interpreted as power, virtue, superiority, excellence. So that authority can be interpreted as strengths and advantages, so that those who have it are called ambawani people; that is, able to regulate, lead and govern, and educate other individuals (Kartono, 1992, p. 183). This can be related to the already popular Javanese term namely ajining diri soko lathi, ajining rogo soko busono which means one's self is valued based on his words, someone's physical value is based on his clothes. 
In English there is the term authority, which if seen means in the dictionary has three meanings, namely authority and power (Echols, 2006, p. 46). Authority can also be interpreted by people whose speech has binding power over others, this can be said that the person has authority (Purwanto, 2014, p. 48). Authority is a type of power (Jackson, 1990, p. 201). A person who has great authority in the eyes of his followers can be called a charismatic leader. The radiant authority from his person is a potential, it can also be likened that the charismatic leader has supernatural powers (Rivi, 2009, p. 89).

In the context of authority, a power is not needed by violence, because authority does not frighten, but rather creates a feeling of reticence and respect. Authority also does not cause coercion, but can present a sense of obedience (Weber, 1947, p. 324). From the various explanations above, it can be concluded that authority is a strength to be admired accompanied by respect so as to bring obedience.

\section{Kinds of Authority}

The Authority (authority) is divided by 3 (three) types namely; traditional authority; charismatic authority; and legal rational authority; Some types of authority that can be explained and as follows:

a. Traditional authority rests on beliefs in the sanctity of immemorial tradition and custom. This type of domination is exercised by tribal chiefs, patriarchs, feudal aristocrats (Allen, 2004, p. 104).

b. Charismatic authority rests on devotion to the exceptional sanctity, heroism or personal magnetism of a heroic figure. Revolutionary leaders, prophets and warriors, for instance, exercise this type of authority (Vanderstaay, 2009, p. 263).

c. Legal rational authority is based on properly enacted rules and is given to office holders rather than specific persons. Bureaucrats and government ministers have authority of this type (Eisenstadt, S.N, 1968, p. 47).

In the world of education, traditional authority is authority that is based on the value passed on to someone (inherited authority). For example, Kiai in pesantren and customary heads who are obliged to maintain traditional values to be implemented by the community. Charismatic authority is the authority that is owned and created by someone because he has the attraction for other people to be followed by others. This authority can be learned and even created by the individual teacher. Legal rational authority is authority that is based on applicable regulations so that inevitably must be obeyed, for example the principal. 


\section{Scope of Authority}

To find out more about authority, the following will explain the scope or dimensions of teacher authority consisting of:

a. Affective Authority which includes: Receiving; Respond; Convinced; Application of Work; and Perseverance.

b. Cognitive Authority which includes: Knowledge; Understanding; Application; Analysis; Synthesis; and evaluation.

c. Skills Authority which includes: Perception; Readiness; Mechanism; Guided Response; Finesse; Adaptation; and origination (Thoifuri, 2008, p. 153).

However, from several sources that have been collected, it can be reformulated that the dimensions of authority of educators or teachers include; a. Spiritual Authority (Rochman, 2012, p. 75); b. Cognitive Authority; c. Affective Authority (Sutisna, 2016, p. 126); d. Authority of Skills; e. Social Authority; and f. Physical Authority (Naim, 2013, p. 52).

In general, all teachers have authority, only with varying degrees. Some are high, some are low, and therefore teachers must do things that can increase authority. The factors that influence the ups and downs of teacher authority include; a. Willingness, compassion, and willingness to devote their trust, assertiveness, consequences and respect; $b$. Honest, responsible, fair, wise, clever, love to the task, diligent, disciplined, forgiving, patient, trying to increase the potential, not irritable, self-control, not arrogant; c. When delivering subject matter the teacher is willing to give reasons, be understanding, be patient and give freedom of opinion for students.

\section{Methods}

This research is a type of qualitative research. Through this research the teacher's authority will be comprehensively analyzed and it is expected to gain a deep understanding and broad knowledge so as to obtain new research findings that have a high level of truth and validity. Authority is the connection between those who carry authority and those who voluntarily acknowledge authority along with compliance. So the authority is not owned as a one-sided power, even though that authority is in a person (Rasyidin, 2014, p. 88). This research was conducted at MTs. An Nahdliyyah Mojokerto, a madrasah that stands under the An Nahdliyyah Islamic Boarding School whose teacher come from inside the pesantren (ndalem) and come from outside the pesantren. Data collection techniques using interview, observation and documentation. To facilitate the determination of students or teachers who 
will be used as data sources, the research subject taking is carried out based on several considerations and predetermined criteria (Sugiyono, 2019, p. 121). The selection of subjects and research informants was done by purposive sampling technique and snowball technique. While the data analysis technique uses a technique initiated by Miles and Huberman where data analysis is carried out together with the data collection process, with analysis activities including data reduction, data display, and conclusion drawing/verification (Miles, 2009, p. 17).

\section{Dimensions of the Authority of Teachers in Madrasah based of Islamic Boarding School}

This research begins by exploring in depth the authority conditions of teachers in MTs. An Nahdliyyah and teachers who are considered the most authoritative. The vision of this Madrasah is the realization of a superior madrasah, which produces graduates who are pious, wise, cultured, accomplished and devoted to their families, nations, countries and religions. While its mission is to maintain quality Islamic education and cultivate the commitment of Islam, humanity, piety, nationalism and; family based on akhlakul karimah (Documentation, 2020). The Qur'an ask us to always be calm and authoritative (Az-Zuhaili, 2014, p. 169). Authority must continue to run in effort to develop the quality of teaching and learning activities and student achievement. As was known at the outset that the dimension of teacher authority includes spiritual authority, cognitive authority, affective authority, skill authority, social authority, and physical authority (Observation, 2020). The six dimensions of teacher authority in MTs. An Nahdliyyah will be presented sequentially, as follows.

\section{Analysis of Spiritual Authority}

Spirituality comes from the word spirit which means spirit or soul or comes from a spiritual word that has an inner or spiritual meaning. Spirituality is a human desire to get closer to the creator. To get close to God, the key words are faith, faith and faith (M. A. Syukur, 2012, p. 67). One indicator of spiritual authority is the strength in mental exercise which includes know in advance of what students will reveal. The teacher is also a figure of someone who has an honorable and noble position, the educator is also said to be a spiritual father to students, who can provide life with knowledge, foster with noble morals, and rectify the despicable deeds. In connection with the vital and important functions of these teachers in Islam, so that teachers are given high dignity, and it is said that the task of educators is the same as the duties of the Rasulullah SAW (Tafsir, 2010, p. 85). 


\section{Analysis of Cognitive Authority}

This authority begins with mastery and in-depth understanding of the subject matter delivered which includes have good basic teaching skills, understand and master the subject matter, deliver the material flexibly and use language that is understandable. Having professional qualifications and having high moral integrity should be owned by the teacher because teachers are the subject of teaching and learning activities. It is also a capital for the application of authority, so that the abilities and potential that exist in students can develop. Teachers also should not be strings attached, because the strings attached are, in addition to being detrimental and burdensome to students, they can also damage the meaning of education and can also reduce the authority of teachers.

\section{Analysis of Affective Authority}

The teacher must have the ability to be confident (not to hesitate) especially on the truth of the material presented, so that the communication is very convincing. A good teacher attitude will make students happy psychological condition and not depressed. This gives the advantage that there is great hope that the students' assignments can be completed properly and enthusiastically. The teacher can make teaching and learning activities fun by providing entertainment in the form of songs and games that are liked by students so that students are always refreshed (Saefuddin, 2016, p. 34). The teacher must be a person who has good morals and has a good personality, including moral and good personality, attractive attitude and personality, never angry, shouting let alone hitting and assertive attitude. As it is known that the teacher must be a good example in various things such as the ability to think, behave, and say that can be seen from his actions. Therefore, teachers should not only act as instructors who convey knowledge, but also instill values to students. This means that the teacher must take several steps forward to guide and give direction to students in learning (Sardiman, 2010, p. 125).

\section{Analysis of Skills Authority}

One of the indicators of authority is the ability to conduct an evaluation process, both materials, learning interactions, including often do tests to measure students' weaknesses or deficiencies in teaching and learning activities, evaluation of learning interactions conducted. This is in accordance with the teacher's function as an assessor, the teacher has to make questions, complete with assessment instruments such as the questions grid, item analysis, and of course the answer key. After that, the question is given to students and evaluates it fairly. Provide remedies for students who have not yet reached the Minimum Mastery Criteria 
(KKM) and provide enrichment for students who have exceeded the KKM. Given the complex responsibilities of teachers, it is expected to be able to divide time during work. Teachers must be skilled in planning and implementing the learning process, assessing learning outcomes, conducting guidance and training, and conducting research and community service (Uno, 2009, p. 25).

\section{Analysis of Social Authority}

Teachers must have the ability to establish comfortable and good communication with students (Elliot, 2009, p. 202), fellow teachers, superiors, employees and the like. The results showed that one component of authority was the ability of teachers to establish external communication (with student guardians, students' families, and communities around the environment where the teacher taught). The importance of teacher ethics is reinforced that teacher ethics are values that organize social interactions such as the relationship between teacher and students, between teacher and student guardians. Especially in the context of religious education, it must have a personality that is characterized so as to create a noble and perfect ethics (Kasnut, 2007, p. 69).

\section{Analysis of Physical Authority}

Appearance certainly has a positive or negative effect. This is in line with the Javanese term namely ajining diri soko lathi, ajining rogo soko busono. An authoritative teacher usually well-dressed also has good writing, including always looks neat, there is no impression of slums and dirty, his writing is good, his writing is simple and very young to read. The results of this study as an indicator of teacher authority, are intended to support the function of the teacher as a class manager who is able to become an idolized figure physically and mentally. The teacher becomes a person who has a clear voice, firm intonation with the use of words and language that is straightforward and easy to understand. Birth states can be used as representations of mental states. Teachers who look good, will have more appeal than teachers who appear mediocre. When it has more appeal, a good impression will be created so that it is easy for the teacher to make variations in the learning methods that include the teacher's position, sound variations, and even variations in learning media (Wiyani, 2014, p. 63).

From the explanation of the aspects of the authority of the teacher which includes spiritual authority, cognitive, affective, skills, social authority, and physical authority, it can be illustrated as follows: 


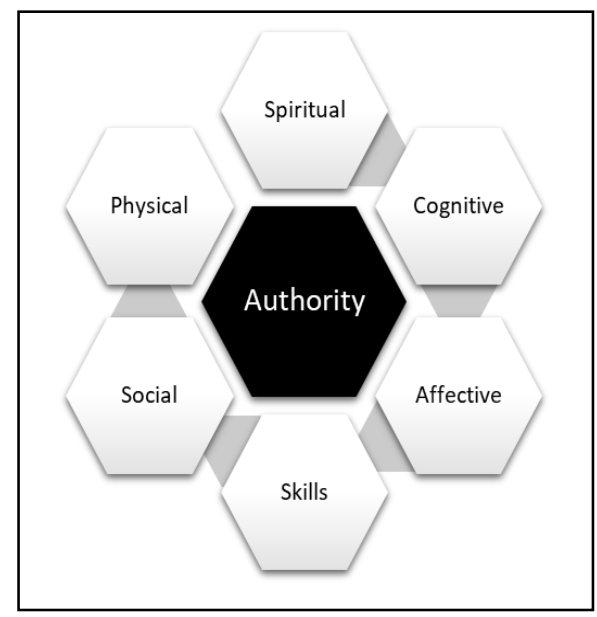

Picture 1. Dimensions of the authority of teachers

All teachers generally have these six aspects of authority, but they may not be perfectly possessed by a teacher, so what needs to be done is an effort to achieve that perfection. Sometimes a teacher has advantages in spiritual authority but lacks in the authority of knowledge. Or sometimes a teacher has a deficiency in physical authority but has an advantage in skill authority. Indeed, it is better if in a school or madrasah, the teaching staff to fill each other's shortcomings, and continue to strive to fulfill aspects of authority. This will certainly make it easier to achieve educational goals.

\section{Factors That Influence the Authority of Teachers in Madrasah based of Islamic Boarding School}

Educational institutions certainly need teachers as implementing education, starting from the planning, process, and evaluation. The teacher is the spearhead for the success of the education process. Success or failure of education, one of the variables that influence is the quality of teachers. Teachers are considered as the central and starting point of all educational development (Surya, 2003, p. 22).

It is authority that causes the teacher to be respected and obeyed, including authority in the classroom. Forming perfect reason is also an obligation that the teacher has in education (Assegaf, 2013, p. 73). Results of research at MTs. An Nahdliyyah based on the results of the interview (Interview MS-1,3,5, 2020) of the several factors that can increase the authority of teachers, at least 3 of the most dominant things that must be done by teachers so that authority is always maintained, even that authority can be increased. It also aims not to burden teachers who want to increase their authority. The 3 things can be formulated as follows: 
Tabel 1. Factors That Increase Teacher's Authority

\begin{tabular}{|c|c|}
\hline Authority factor & Indicator \\
\hline 1. Assertiveness & $\begin{array}{l}\text { - Serious and serious in the delivery } \\
\text { of material. } \\
\text { - Not a lot of jokes outside of the } \\
\text { material but still fun } \\
\text { - Decisive in decision making } \\
\text { - Commit to carrying out the } \\
\text { decision. }\end{array}$ \\
\hline 2. $\quad$ Responsibilities & $\begin{array}{l}\text { - Responsibilities in educating, } \\
\text { - Rarely does not enter. } \\
\text { - Try as hard as possible to make } \\
\text { students understand the subject } \\
\text { matter. } \\
\text { - Trying to look good when } \\
\text { delivering course material even if it's } \\
\text { a bit sick. }\end{array}$ \\
\hline 3. Patience & $\begin{array}{l}\text { - Not easy to be angry and not say } \\
\text { rude } \\
\text { - A figure that easily forgives } \\
\text { - Anger is an alternative to last resort }\end{array}$ \\
\hline
\end{tabular}

\section{Assertiveness}

Decisive action is important. An authoritative teacher is synonymous with assertive behavior. The teacher's effort to make students understand the material provided requires assertiveness. Assertiveness is also needed to educate students to have good values, in accordance with religion and the surrounding environment. Without firmness it will be more difficult for teachers to teach and educate, about the values that are important for the future of students. Teachers must strive as optimal as possible to deliver students achieve maximum achievement with the talent possessed by students (Arifin, 1995, p. 163).

Decisive action must have educational value, with the hope of changing the behavior of students who are not good to be good, who are already good for the better. Of course, this positive change is based on student awareness, not just coercion. There are a number of minimal things that must be done in implementing strict action in educating, namely students must be aware of mistakes, there is hope to be better, there is no violence, and still maintain a good relationship between teacher and students (Prayitno, 2008, p. 53). 
Furthermore, the actualization of decisive actions taken by the teacher should be accompanied by affection and gentleness, there is no distance and gap between the teacher and students so that productivity can still be achieved. Compassion and gentleness are the most basic psychological needs in life and human life (Sukardi, 2006, p. 63). This has already been explained in Al-Qur'an Surah Ali Imron verse 159 which reads:

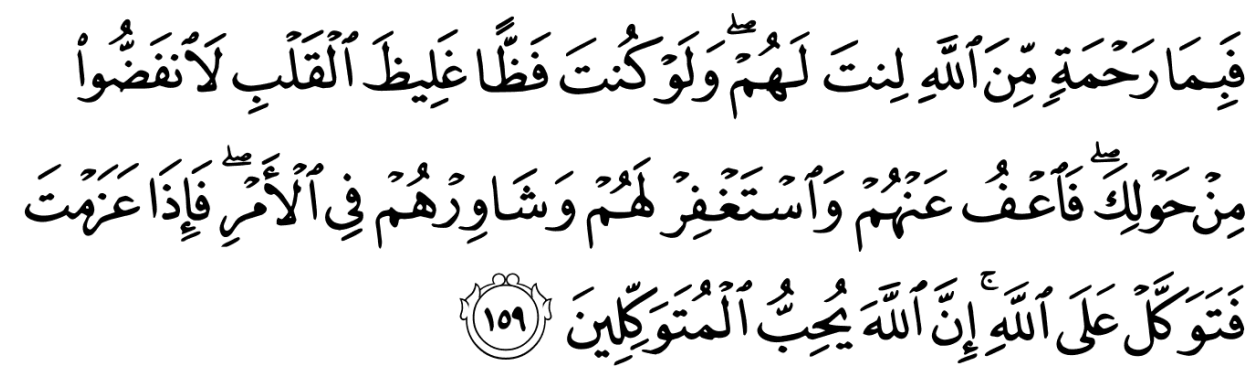

"So, by mercy from Allah, (O Muhammad), you were lenient with them. And if you had been rude (in speech) and harsh in hearth, they would have disbanded from about you. So pardon them and ask forgiveness for them and consult them in the matter. And when you have decided, then rely upon Allah. Indeed, Allah loves those who rely (upon Him)” (Surah Ali Imron, 159)

The results of the study show that there are firm personalities of authoritative teachers such as speech and intonation of a serious tone of speech, and commitments agreed upon together, giving penalties in accordance with the agreement, the use of the language is subtle but dense, his words are always serious but relaxed, not breaking promises, serious and truly in the delivery of material, there is no joke outside the material lesson, firm in decision making and committed to carrying out the decision (Interview, 2020). This assertiveness must not distance the teacher and students, so it must be truly proportional. Educated with ethics, aesthetics, compassion, and care, so the students grow to become knowledgeable and qualified human beings in the future (Rozi, 2019, p. 243).

\section{Responsibility}

The teacher as the implementer of education, must be responsible for students, students, students, students or with other similar terms (Tafsir, 2010, p. 74). These responsibilities include assignments inside and outside of school. And it must be remembered that the teacher must not leave his responsibilities because all will be responsible for what has been done, as the word of Allah in Al-Qur'an Surah Al Mudatsir Verse 38 which reads: 


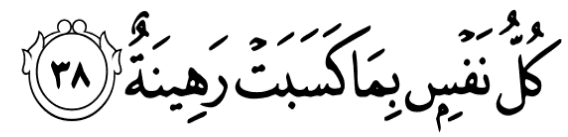

"Every soul, for what it has earned, will be retained". (Surah al-Mudatsir, 38)

Furthermore, the teacher is a figure of uswatun hasanah in many ways, more specifically in terms of morals. Teachers should also have a moral burden to shape their students to become faithful and knowledgeable people. So teachers should always remember their duty to carry out learning and education as a whole (Ma'arif, 2012, p. 26).

The central role of the teacher and the responsibilities assumed, requires the figure of a teacher who is responsible. The results showed that the responsible personality, as one of the factors of the teacher's authority, was identified through the following matters: he did not leave the classroom when the teaching and learning process was still ongoing, except when there was something urgent, a figure who was ready to bear the risk of each decision taken, teaching full time, the desire to understand all students on the subject matter delivered, no time wasted in vain, the provision of subject matter is completed on time, according to the target, and the responsibility in educating despite being sick (Interview, 2020).

\section{Patience}

Patience is an attempt to refrain from anything that is not liked because they expect the pleasure of Allah. Patients who have patience must have the courage to endure various kinds of difficulties as an effort to prevent actions that are not liked and in order to carry out worship and commendable actions, as well as endurance in avoiding despicable actions (Al-Maraghi, 1992, p. 110).

Patience is one of the noble morals, the teacher must have noble morals to be an example for students, because students are more likely to imitate teachers' actions than the teacher says. So the teacher not only conveys knowledge to students but is also expected to instill spiritual values that will provide students with provisions to always fill their days with praiseworthy deeds (Tafsir, 2010, p. 48).

In carrying out and instilling noble morals, the teacher must cooperate with various parties including the community. So that the teacher remains consistent in being patient and authoritative in the eyes of students (Djamarah, 2010, p. 34). Patience must be attached to the teacher as a personality in life. Patience should not be interpreted as resignation or ignorance, but as a stronghold of the teacher, so that the teacher is not easily angry or even mock students, 
because that would damage the teacher's authority (Ghazali, 1964, p. 217). Teachers must be able to hold back, be patient, and be more patient even though students often make teachers angry and even violate school rules. As the word of Allah Almighty in the Al-Qur'an Surah AnNahl verse 126 which reads:

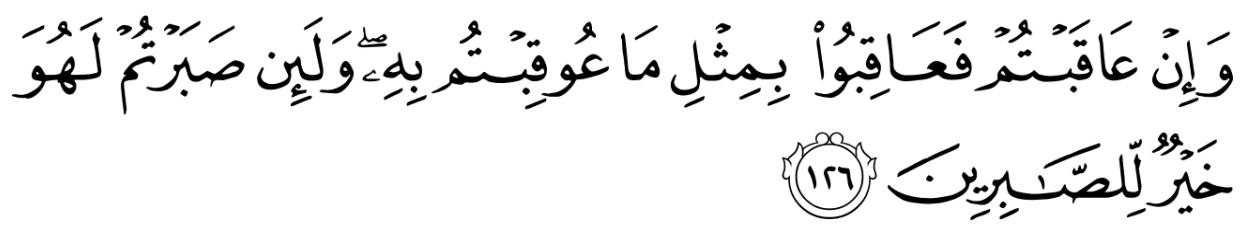

"And if you punish (an enemy, $\mathrm{O}$ believers), punish with an equivalent of that with which you were harmed. But if you are patient, it is better for those who are patient." (Surah an-Nahl, 126)

The patient attitude that the teacher has makes it easier to be accepted by students, because everyone would prefer to be treated subtly. Under these conditions, learning activities will be more conducive to making it easier for teachers to achieve educational goals. Patiently, educational goals can be achieved with more direction without being offensive because the teacher is present not as part of the problem, but as part of the solution, not on violence, both violence in the system, violence in material, and violence in teaching methods (Assegaf, 2004, p. 23).

5. The Dynamics of Teacher's Authority in Madrasah based of Islamic Boarding School

As the previous explanation that authority is divided into 3 types, namely; Traditional authority; Charismatic authority; Legal rational authority (Borgatta, 2000, p. 229). As Weber's theory, authority is divided into 3 types, namely, Traditional authority; Charismatic authority: Rational legal authority. This study is a useful tool to demonstrate the inherent authority of the teacher and to offer a broader nuance in looking at the characteristics of a leader, the origin and transformation of authority (Mas'ud, 2004, p. 27). The results showed that the authority of teachers in MTs. An Nahdliyyah who came from inside pesantren (ndalem) in the form of traditional authority, while teachers from outside pesantren had to try to get their authority in the form of charismatic authority or even legal rational authority. This can be described as follows: 


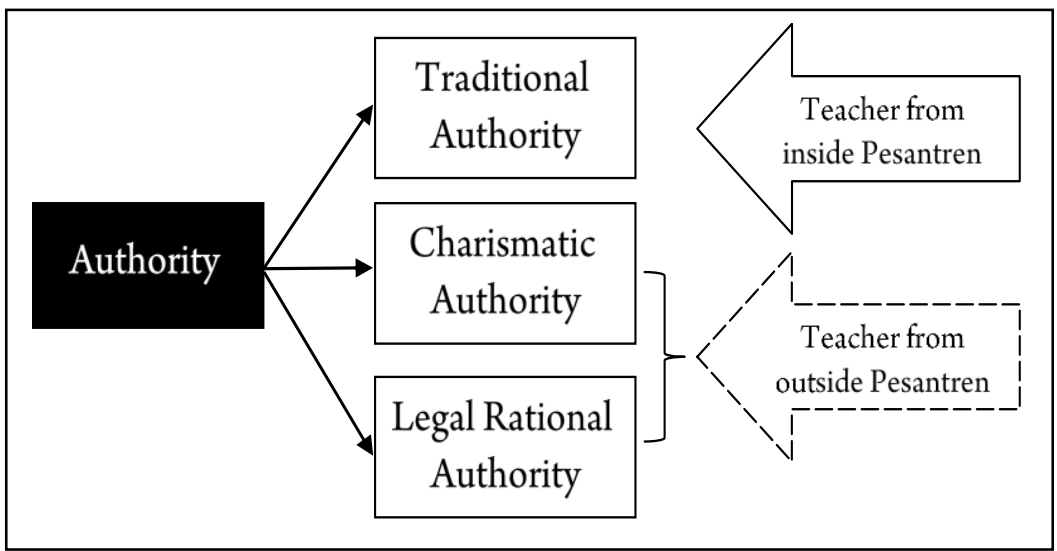

Picture 2. The authority position of teachers in MTs. An Nahdliyyah

There are many opportunities that teachers can do in general to get authority from any path. Teachers from outside the pesantren must work harder to get their authority. But sometimes these efforts fail so that the emergence of diverse perceptions of students towards the authority of teachers, or the imbalance of students' perception of authority of teachers who come from inside the pesantren (ndalem) and teachers from outside the pesantren. Teachers from ndalem are more respected and considered authoritative, while teachers from outside pesantren are considered not authoritative. As the findings of previous research that there are 3 (three) types of student perceptions related to the authority of teachers in MTs. An Nahdliyyah, namely: 1) Teachers who are not authoritative (underestimated); 2) Authoritative (admired) teacher; 3 ) Teachers who are too authoritative (feared) (Rohmad, 2016, p. 381).

This is like the leadership typology of different pesantren Kiai. The kinds of pesantren leadership patterns are 1) charismatic leadership, 2) traditional leadership, 3) traditional charismatic leadership, 4) rational leadership, 5) charismatic, traditional, rational leadership (Nasir, 2004, p. 262). The typology of pesantren leadership above has implications for the policies it takes in managing the pesantren. Both the curriculum, methods, and output produced by each pesantren differ according to the typology of Kiai's leadership (Suharto, 2018 , p. 55). We do not need to compare between the authority possessed by teachers from inside and outside the pesantren. All teachers must have authority that is appropriate to the needs of students, not only individual authority, but also authority that is collective, so that educational goals will be achieved easily. However, it must be realized that everything has positive impacts and negative impacts. The positive impact of a teacher who has authority in accordance with student needs, including: 
a. The teacher will be admired, respected, and obeyed by students,

b. Students will obey the rules based on awareness and without coercion,

c. Can form a good and polite personality,

d. The emergence of student love for the teaching and learning process

e. The development of a democratic attitude in students.

While the negative effects of a teacher who has excessive authority, including:

a. Lowering and even turning off student leadership potential,

b. Resulting in a rigid regulation because the teacher's very dominant role,

c. Resulting in students who are less creative,

d. Compliance with regulations due to fear and not awareness,

e. The development of attitudes that tend to be authoritarian (Interview MS-1,3,5, 2020).

If students have reached maturity because of the education process, the teacher's authority will be recognized by itself and of course voluntarily carry out what has been said. From the various explanations above, the dynamics of teacher authority in Madrasah based of Islamic boarding school must always be monitored for their changes and shifts. Because it is feared that the authority of the teacher will be lost in the future.

\section{Conclusion}

Authority is interpreted as a strength to be admired accompanied by respect to bring obedience. The authority of teachers in Madrasah based of Islamic boarding school has 6 dimensions which include spiritual authority, cognitive authority, affective authority, skills authority, social authority, and physical authority.

There are many factors that can increase the authority of a teacher, but at least 3 things must be done by the teacher so that the authority can increase, namely assertiveness, responsibility, and patience. With these three factors the teacher can maintain and even increase his authority without being abandoned by students.

The authority that occurs in Madrasah based of Islamic boarding school includes the authority of teachers who come from inside pesantren (ndalem) in the form of traditional authority, while teachers from outside pesantren must try to get their authority in the form of charismatic authority or even legal rational authority. But sometimes these efforts meet obstacles so that the emergence of a variety of student perceptions of the authority of teachers, namely: 1) Teachers who are not authoritative (underestimated); 2) Authoritative (admired) teacher; 3 ) Teachers who are too authoritative (feared). 
The recommendation for teachers is that the teacher must continue to strive to create as much authority as possible. Managers of educational institutions, especially those under the auspices of Islamic boarding schools, need to pay attention to the authority of teachers, especially those from outside the pesantren. In addition, material on teacher authority should be taught in Higher Education, so that graduates are able to become authoritative teachers even as new teachers. Because new teachers have the potential to be underestimated by students, because their abilities have not been proven and tested.

\section{REFERENCE}

Abdillah. (2012). Relevansi Kewibawaan dan Kewiyataan dengan Hasil Belajar Siswa. Nadwa; Jurnal Pendidikan Islam. Vol. 6 No. 2.

Allen, K. (2004). Max Weber: A critical introduction. Pluto Press.

Al-Maraghi, A. M. (1992). Tafsir Al-Maraghi (Terj). Thoha Putra.

Arifin. (1995). Kapita Selekta Pendidikan Islam dan Umum. Bumi Aksara.

Assegaf, Abd. R. (2004). Pendidikan Tanpa Kekerasan: Tipologi Kondisi, Kasus dan Konsep. Tiara Wacana.

Assegaf, Abd. R. (2013). Aliran Pemikiran Pendidikan Islam. Raja Grafindo.

Asy'ari, H. (1238). Adab al-'Alim wa al-Muta'allim fi Ma Yahtaju ilaihi al-Muta'allim, (Jombang: Maktabah Turots Islami,1238. Maktabah Turots Islami.

Az-Zarnuji. (tt). Ta'lim al-Muta'alim. Maktabah Al Hidayah.

Az-Zuhaili, W. (2014). Wahbah Az-Zuhaili, Akhlak Muslim; Berakhlak dalam Bermasyarakat, (Jakarta: Noura Books, 2014. Noura Books-Mizan Publika.

Bahrizi, A. (2005). Ahmad Bahrizi, Holistika Pemikiran Pendidikan A. Malik Fadjar, (Jakarta: Remaja Rosdakarya, 2005. Remaja Rosda Karya.

Borgatta, E. F. \& R. J. V. M. (2000). Encyclopedia of Sociology. Macmillan Reference.

Danim, S. (2006). Agenda Pembaruan Sistem Pendidikan. Pustaka Pelajar.

Dhofier, Z. (2011). Tradisi Pesantren: Studi tentang Pandangan Hidup Kiai dan Visinya Mengenai Masa Depan Indonesia. LP3ES.

Djamarah, S. B. (2010). Guru dan Anak Didik dalam Interaksi Edukatif. Rineka Cipta.

Echols, J. M., dan Hassan Sadily. (2006). Kamus Inggris Indonesia (XXVIII). Gramedia. 
Eisenstadt, S.N. (1968). Max Weber on Charisma and Institution Building. Univercity Of Chicago.

Elliot, J. G. (2009). The Nature of Teacher Authority and Teacher Expertise. Vol. 24 No. 4.

Firdaus, A. M. (2019, February 25). Kasus Siswa Melawan Guru, Mendikbud; Guru harus jaga Wibawa. Ayo Bandung.Com.

Freire, P. (2008). Pendidikan Kaum Tertindas (Terj). Pustaka LP3ES.

Ghazali, A. (1964). Ihya' Ulumuddin, Menghidupkan Ilmu-ilmu Agama (Terj). Faizan.

Ilmi, D. (n.d.). Kewibawaan (High Touch) Sebagai Media Pendidikan Karakter. Islam Transformatif: Journal of Islamic Studies, Vol. 1 No.1, 2017.

Jackson, K. D. (1990). Kewibawaan Tradisonal, Islam, dan Pemberontakan. Grafiti Press.

Kartono, K. (1992). Pengantar Ilmu Mendidik Teoritis. Mandar Maju.

Kasnut. (2007). Etika Dalam Pendidikan; Telaah Atas Pemikiran Immanuel Kant. Vol. 5 No. 1.

KBBI, T. P. K. P. B. (2002). Kamus Besar Bahasa Indonesia (2nd ed.). Balai Pustaka.

Ma'arif, S. (2012). Guru Profesional: Harapan dan Kenyataan. Need's Press.

Maatta, K. \& S. U. (2012). Pedagogical authority and pedagogical love, connected or incompatible? International Journal of Whole Schooling. Vol 8.

Manurung, R. T. (2008). Terhempasnya Wibawa Guru: Satu Kajian Kontrastif Karya Sastra Masa Kini Dan Masa Lalu. Vol. 15 No. 7.

Mas'ud, A. (2004). Intelektual Pesantren. LKiS.

Miles, M. B. \& A. M. H. (2009). Qualitative Data Analysis (Terj). UI Press.

Munawwir, A. W. (2002). Kamus Al Munawwir. Pustaka Progessif.

Naim, N. (2013). Menjadi Guru Inspiratif. Pustaka Pelajar.

Nasir, R. (2004). Mencari Format Tipologi Pendidikan Ideal, Pesantren di Tengah Arus Perubahan. Pustaka Pelajar.

Prasetyawati, P. (2016). Analisis Pembelajaran Berbasis Student Centered Learning. Vol. 4 No. 10.

Prayitno. (2008). Dasar teori dan praksis. Gramedia Widia Sarana.

Purwanto, M. N. (2014). Ilmu Pendidikan Teoritis dan Praktis. Rosda Karya.

Rasyidin, W. (2014). Pedagogik Teoritis dan Praktis. Remaja Rosda Karya.

Rivi, V. \& S. M. (2009). Education Management: Analisis Teori dan Praktik. Rajawali Press. 
Rochman, C. \& H. G. (2012). Pengembangan Kompetensi Kepribadian Guru: Menjadi Guru yang Dicintai dan Diteladani Oleh Siswa. Nuansa Cendikia.

Rohmad, M. A. (2016). The Dynamics Authority of Pesantren. Repository.Uin.Malang.Ac.Id.

Rozi, S. (2019). Strategi Kontra Radikalisme Agama Melalui Pendidikan Budaya dan Kewargaan Berbasis Pengasuhan; Studi Pemikiran KH. Asep Saifuddin Chalim. Prosiding SNP2M UNIM.

Saefuddin, A. \& I. B. (2016). Pembelajaran Efektif. Remaja Rosda Karya.

Sardiman. (2010). Interaksi dan Motivasi Belajar Mengajar. Rajja Grafindo Persada.

Shiddiq, T. (2018, November 13). Video Viral Guru Dikeroyok Siswa, Mendikbud: Guru Jaga Wibawa [Tempo.co].

Sugiyono. (2019). Metode Penelitian Kualitatif. Alfabeta.

Suharto, B. (2018). Pondok Pesantren dan Perubahan Sosial. Pustaka Ilmu.

Sukardi, D. K. (2006). Pengantar Pelaksanaan Program Bimbingan dan Konseling di Sekolah. Rineka Cipta.

Surya, M. (2003). Percikan Perjuangan Guru. Aneka Ilmu.

Sutisna, U. (2016). Pengaruh Kewibawaan Guru PAI terhadap Motivasi Belajar Siswa SMK AlKautsar. Vol. 3 No. 2.

Syukur, F. (2002). Dinamika Pesantren dan Madrasah. Pustaka Pelajar.

Syukur, M. A. (2012). Kuberserah. Noura Books-Mizan Publika.

Tafsir, A. (2010). Ilmu Pendidikan Dalam Perfektif Islam. Remaja Rosda Karya.

Thoifuri. (2008). Menjadi Guru Inisiator. Rasail.

Tirri, K. \& T. P. (2000). Teacher Authority In Schools: A case study from Finland, Journal of Education for Teaching.

Uno, H. B. (2009). Mengelola Kecerdasan Dalam Pembelajaran. Bumi Aksara.

Vanderstaay, S. L. \& B. A. F., Jack E. Meischen, Karlene T. Kolesnikov, and Andrew D. Ruppel,. (2009). Close to the Heart: Teacher Authority in a Classroom Community.

Weber, M. (1947). Theory of Social and Economic Organization. The Falcon Wing Press.

Wiyani, N. A. (2014). Manajemen Kelas, Teori dan Aplikasi Untuk Menciptakan Kelas yang Kondusif. Ar-Ruzz Media. 